\title{
The Impact of Financial Risk Factors on Key Performance Variables in the Nigerian Petroleum Industry
}

\author{
Christiana Ogulu ${ }^{1 *} \quad$ Cecil Arnolds ${ }^{2} \quad$ Louis $\mathrm{Njomo}^{3}$ \\ Jugathambal Ramdhani ${ }^{1}$ \\ 1.University of KwaZulu -Natal, Private Bag X03 Ashwood Pinetown 3605 \\ 2.Mandela University Business School, Port Elizabeth, South Africa \\ 3.Advanced School of Economics and Commerce, University of Douala. Douala, Cameroon
}

The authors would like to thank the three anonymous reviewers and the editor for valuable comments and suggestions on earlier versions of this paper

Abstract

The Nigerian petroleum industry is central to the sustainability of the economy of Nigeria as it is the greatest contributor to Gross Domestic Product (GDP) and foreign exchange. The recurring nature of price risk and other financial risks in the petroleum industry suggests that uncertainty, driven by oil and gas price changeability, causes incessant apprehension to all stakeholders who suggest a need for effective management if sustainability of the industry is to be achieved. Risk management is said to be in a rudimentary stage in Nigeria and, at best, evolving. Previous literature in this area mostly focuses on the impact of each risk on the company's stock and exporting countries' economies. Research on integrated financial risks' impact on key operational variables in the Nigerian petroleum industry is scarce. This study was, therefore, conducted to fill that gap by contributing to the literature on financial risk management. It examined the impact of financial risk factors on key performance variables, such as profitability, cash flow, the cost of doing business, workforce cutting and project shelving in the Nigerian petroleum industry. This study adopted a mixed-method research design with a philosophical stand, which is associated with the pragmatism paradigm. Qualitative and quantitative data were collected by conducting semistructured interviews with five senior management staff and distributing questionnaires to 70 financial risk managers. Descriptive and inferential statistics, such as the Pearson correlation coefficient, were used to determine the significance of the relationship. These results indicated that there was a significant relationship between financial risk factors and key performance variables such as profitability, cash flow and the cost of doing business at a value of $\mathrm{P}<0.05$. These results are important to the financial risk managers and stakeholders of the industry as it will help them understand how to manage their exposure for sustainability.

Keywords: Nigerian Petroleum Industry, Financial Risks, The Impact of Financial Risks, Exchange Rate Exposure and Price Risk Exposure

DOI: $10.7176 / \mathrm{EJBM} / 12-14-10$

Publication date:May $31^{\text {st }} 2020$

\section{Introduction}

The determination of financial risks' impact on businesses' objectives has been a subject of numerous studies as the knowledge of the magnitude of the effect of these risks guides management's response as financial risks impacts the financial well-being of companies, including the Nigerian petroleum industry. Oil prices have been found to generate more of a spill-over effect in all areas of the world economy than any other commodity (Algieri \& Leccadito, 2017). Oil prices affect exchange rates through both supply and demand channels (Nikbakht, 2010). Oil price upsurges impact production negatively since oil is a basic ingredient of production resulting in short supply and high demand for a non-productive factor which in turn impacts exchange rate and prices.

The petroleum industry plays a pivotal role in the economy of Nigeria, for customers, contractors, employees and shareholders. Petroleum production and exportation have become the backbone of the Nigerian economy (Oladepo, 2014, p. 80). The revenue derived by the Nigerian government from the exportation of petroleum products accounts for 96 per cent of total exports according to the International Monetary Fund (IMF) in 2012. In addition to export revenue, Nigerians depend heavily on the petroleum industry for their energy needs, transportation, cooking, power and micro-industries that assist in reducing unemployment (Odularu, 2007).

Even though Nigeria is one of the leading oil-producing countries of the world (Energy Information Agency (EIA)) (2013), it is categorised as one of the poorest countries in the world according to Arong \& Ikechukwu (2013, p. 123). One of the major issues is that Nigeria exports raw products, oil and gas, and imports several petroleum products, such as fuel, diesel and kerosene at a higher cost than the exported products. Therefore, any gain derived from exports becomes a loss in the process of importation, which is destroying the economy of Nigeria (Arong \& Ikechukwu, 2013). Consequently, any issue that will destabilise this all-important industry will also destabilise the economy of Nigeria. Financial risks arise as a result of unexpected variability in exchange rates, interest rates, prices of products and credit risk (Prasad \& Suprabha, 2015). Over the past decade, Nigeria has experienced a substantial depreciation in the value of its currency concerning the US dollar exchange rate. These changes in 
financial risk factors are more evident in the petroleum industry as oil and gas prices are not determined by the forces of supply and demand, but by several economic factors (Talbot, Artiach \& Faff, 2013).

Arong \& Ikechukwu (2013) suggest that an effective risk management system, which is not based on the use of derivatives alone, needs to be implemented for the survival of the Nigerian petroleum industry. Jorion (2009) is of the view that one can only manage risk if one is aware of its existence and has calculated its magnitude accurately. Stulz (2008 p. 41) stresses that two types of blunders can occur in computing risks' impact on businesses, "(1) Known risks can be miss-measured, and (2) important risks can be ignored, either because they are undetected or wrongly viewed". Therefore, the determination of accurate financial risks' effect on the objectives of companies in the Nigerian petroleum industry is very important for its sustainability.

The determination of the impact of financial risk factors on the objectives of a company is one of the most important steps in the risk management process (Hekman, 1989). It is important to know the exact scale of risks that a company is exposed to at a point in time before using an applicable response (Woods \& Dowd, 2008). Financial risks influence the financial performance of companies (Noor \& Abdalla, 2014). Managerial actions may be in the form of taking up the risk, divesting, transferring, risk sharing, delaying actions or managing risk through a variety of strategies (Woods \& Dowd, 2008).

Articles on the determination of the impact of exposure on organisations have used an assortment of models, such as value at risk, cash flow at risk, the capital assets pricing model, and the impact of stock prices, but those that rely on the views of those who manage these risks are few (Talbot et al., 2013; Andriospoulos \& Nomikos, 2012; Hong \& Sarkar, 2008). These articles exclusively appraise each financial risk, such as oil price exposure, exchange rate exposure or interest rate exposure on the stock market or economic level and the results are mixed (Talbot et al., 2013).

Remarkably, the wide-ranging variety of studies in the field of risk management has focused on using historical data to determine the impact of financial risks on the shares of companies and, as such, has found mixed results (Jongen, Muller \& Verschoor, 2012). The plausible explanation for the difficulties experienced in reporting the significant impact of foreign exchange risk on share market values is that organisations are conscious of their foreign exchange risk and are limiting it through hedging (Bartov \& Bodnar, 1994). The researchers of previous studies have contributed greatly to financial risk management, but the use of historical data means that actual exposure must have been altered by the company's financial risk management activities, as found by Talbot et al. $(2013$, p. 1) when they investigated factors that "drives commodity price beta of oil stock". This study integrated risk managers' view of the impact of the various financial risks on the key performance variables of the Nigerian petroleum industry to bridge the gap in the literature on risk management.

The Central Bank of Nigeria has stated that risk management is in a 'rudimentary stage' and developing at best. The literature on the impact of financial risk in the Nigerian petroleum industry is scarce. Studies in Nigeria are more interested in the prices of oil and the economy, such as those of Tule, Ndakob \& Onipede, 2017; Stober, 2016; Chaudary, Nisar, Talat \& Salvador-Adebayo, 2014. This study, therefore, filled that gap.

The rest of this article is structured as follows: The next section examines literature relating to the impact of financial risk factors on organisational performance. This is followed by a discussion of the research methodology before the data presentations and discussion. The article concludes with a summary of key findings; implications for stakeholders, possible limitations and suggestions for future research.

\section{Review of Related Literature}

The Nigerian petroleum industry is the backbone of the Nigerian economy. According to Bagehot \& Atima (2015, p. 2) "oil provided approximately 90 per cent of foreign exchange earnings and about 80 per cent of federal revenue and contributes to the growth rate of Gross domestic product (GDP)" of Nigeria. The wake of the oil price crash has created exceptional fluctuation in exchange rates, interest rates and a series of divestment in the Nigerian petroleum industry. To guarantee that financial distress will not set in to reduce growth in the Nigerian petroleum industry, risk management is indispensable. According to the Central Bank of Nigeria, these financial risk factors also impact on the Nigerian economy, which depends on this petroleum industry for foreign exchange inflows resulting in a net deficit currency inflow of N1 150 billion in 2015 and a deficit current account of N3 033 billion. As stated above, numerous researchers have validated each financial risk impact on the economy in general or on the stock market price, however, none have studied the impact of the combined effect of all financial risks on the Nigerian petroleum industry. Tule et al. (2017) posit that oil prices market impacts families, companies, countries and global economies as oil price changeability are regularly transferred to every other sector of the economy.

Risk is described as the uncertainty of event outcomes which may have a helpful or adverse effect on the business's objectives (Damodaran, 2008). Financial risk arises as a result of exposure to variability in market prices, transactions with other organisations, internal processes, people and systems (Horchers, 2005: 3 ). The effect of changes in commodity prices, interest rates, and exchange rates create incentives for companies to manage financial risks to overcome the downside of these risks. The other risks that do not branch from market forces such as liquidity, credit and demand and supply risks arise from the transaction with other organisations (Wiener \& 
Brunner-Kirchmair, 2019).

Currency risk is the sensitivity of business objectives such as operating income and cash flows to exchange rates variability (Hekman,1989). Foreign exchange risk exposure is the unfavourable movement of the value of the local currency against major trading partners currencies such as the US Dollar. Exchange risk fluctuations play a major role in an oil company's performance as the business of an oil company is internationally operated (Noor \& Abdalla, 2014).

Interest rate risk is another main financial risk that companies encounter in their day to day operations (Dhanani, Fifield, Helliar \& Stevenson, 2008). Companies operating in the oil industry in Nigeria are exposed to diverse sources of funding, within and outside Nigeria, to meet expected funding costs. They are therefore exposed to interest rate changeability. Interest rate risk is the sensitivity of operational income and cash flows caused by interest rate movements (Buckley, 2004: 331).

Commodity exposure is the variability of prices of commodities such as oil and gas that may result in monetary losses to companies in the oil industry. The single largest variable that affects oil companies' ability to perform their operational and financial functions is the price of crude oil and gas (Eni, 2013: 174). Others are supply-demand risk which results from-supply-demand imbalances in many industries, including the oil and gas industry (Tomlin, 2014). Liquidity risk is the risk that the business will not be able to pay its obligation as at when due that could threaten the financial position of the establishment.

Some studies have examined the impact of the oil price on companies' stock and economy, and have found mixed results, for example, Kayalar, Küçüközmen \& Selcuk-Kestel (2016) investigated the impact of changes in oil prices on the financial indicators of global markets and economies, and found a significant relationship between oil prices and exchange rates and share prices of most oil exporter countries, while emerging oil importer markets are not as susceptible to changes in oil prices. In contrast, Dhaoui \& Khraief (2014) found a negative association between oil price changeability and stock prices of eight countries from data from 1991 to 2013. Kolodziej, Kaufmanna, Kulatilaka, Bicchetti \& Maystre (2014) examined the effect of daily unrefined oil prices' variability on equity prices and commodity markets and found correlations between daily returns to crude oil and equity changes from negative to positive due to the interest rate factor. Basher, Haug \& Sadorsky (2012) concluded that positive oil prices shock determines emerging market oil and gas industry shares. Ahmed, Bashar \& Wadud (2012) found that an increased oil price produces a dampening effect on US industrial production.

On the other hand, oil prices were found to have a negative correlation to share prices and the authors concluded that a single commodity should not be taken as an asset class as it is predominant in academic literature (Brook \& Prokopezuk, 2011). A study that analysed oil price risk exposure of U.S. financial and non-financial firms from 1983 to 2015 found a lower impact on financial firms than that of the non-financial firms (Shaeri, Adaoglu \& Katircioglu, 2016). The oil price variability shock on the international stock market was investigated through supply and demand exposures and was found to have no significant relationship (Apergis \& Miller 2009). George Ouma \& Were (2013) found a negative correlation between sugar price variability and profitability. Others, who have looked at the effect of oil prices on shares prices, are Sadorsky (2012), Askari \& Krichene (2008), Elyasiani, Mansur \& Odusami (2011), Arouri, Rault \& Nguyen (2012), Ewing \& Malik (2015); and Tule et al. (2017).

Zahariev \& Kostov (2016, p. 2) defined the global exchange market as "a set of institutions, instruments, technical means of global communication, payment systems and rules for accounting and settlement by which the parties that supply and demand currency and currency denominated financial assets perform counter transactions with exchange effects on an agreed date". These transactions result up and down oscillations in exchange rates also referred to as exchange rate volatility could be described as periods of domestic currency appreciation or depreciation (Ojongbo, 2014). Exchange rate movement creates uncertainties for companies that import or export products, such as the oil industry as transactional, translational or economic exposure (Prasad \& Suprabha, 2015). Herkman (1989, p. 50) defines currency exposure as "the sensitivity of some corporate objectives variable to changes in the foreign exchange rate".

Some researchers concentrate on how exchange rate variability has impacted stock market returns for investor's decision making or on the economy and, as with price risk, the results are varied. Studies that have found evidence of positive correlation between exchange rate and companies' value are those of Gao (2000) who investigated the effect of currency changes on American multinationals and discovered positive effects on shares of companies that deal with foreign sales and negative effects on foreign production. The study of Ye, Hutson \& Muckley (2014) found that owing to the non-floating exchange rate regime, more companies are significantly exposed to exchange rate instabilities in emerging markets. Moore \& Wang (2014) found proof of interest rate exposure in developed economies and negative correlation of exchange rate exposure but found evidence of exchange rate exposure in emerging Asian markets. Lin (2012) found a significant relationship between the exchange rate and stock prices during a crisis in Asian emerging markets as a result of the capital account balance. Nkalu, Urama \&Asogwa (2016) finding indicate that trade liberalisation in Nigeria impacts positively to an extent of (59 per cent) on the exchange rate fluctuations or volatility in Nigeria. The exchange rates variabilities harm the 
Nigerian economy (Umaru, Aguda, \& Davies, 2018; Ehikioya, 2019)

There is a more visible negative correlation between exchange rates and stock value when the exchange rate is either very low or very high (Tsai, 2012). Zhao (2010) did not find any sustained significant relationship between the exchange rate and company stock in China. Kamau, Inanga \& Rwegasira (2015) investigated the impact of currency risk and the performance of multinational banks and found no significant impact of these risks in the financial performance of banks.

Financial risk management is a possible explanation for the mixed results of the impact of foreign exchange on a company's value, as shown by these studies. Bartram, Brown \& Minton (2010) found that financial and operational hedging reduced a currency's fluctuation impact on a company's financial performance by 40 per cent and 15 per cent respectively. The finding of Hutson \& Laing (2014) indicated that operational hedge and financial hedge drastically reduced the efficiency of exchange rate risk on a company's financial performance. Huanga, Kabir \& Zhang (2016) also found that the impact of foreign exchange on a company's value was reduced using derivatives. The plausible explanation for an irregular empirical significant exchange rate exposure is that companies exploited linear hedging instruments, such as forward and futures (Chow, Lee \& Solt, 1997). Al-Shboul \& Alison (2009) found that companies reduced their share price volatility by using derivatives to manage financial risks.

\section{Research Methodology and Analytical Technique}

This paper analyses financial risk managers' view of the impact of financial risks on the Nigerian petroleum industry's key performance variables. This study was based on a survey of the views of financial risk managers enlisted on the membership list of the Petroleum and Natural Gas Senior Staff Association of Nigeria as at July 2016. From the list, a convenience sample of 100 individuals from 33 actively operational oil companies was selected and questionnaires were distributed to them. Only 70 respondents eventually participated, which translated to a $70 \%$ response rate. A descriptive statistic, namely frequency, percentages, rank, and mean, was used. The inferential statistic - Pearson correlation coefficient, was employed to determine the significance of the perceived relationship between the identified financial risks and key performance variables in the companies. Content analysis was used to analyse the interviews of five financial risk experts in the petroleum industry to validate the data, which was collected from the survey. Interviewee names were replaced by pseudonym ( $\mathrm{Mr} \mathrm{A}$, $\mathrm{Mr} \mathrm{B}, \mathrm{Mr} \mathrm{C}, \mathrm{Mr} \mathrm{D}$ and Mrs) to protect their identities. Qualitative and quantitative data were collected, coded and evaluated with the aid of Statistica Version 10 using descriptive and inferential statistical tools (Pearson correlation analysis).

Descriptive statistics (mean scores, standard deviations and percentages) were calculated on the questions. A multiple regression analysis was conducted on the relationships between the financial risk factors (the independent variables) and the key performance variables (the dependent variable). The validity and reliability of the data were also evaluated by conducting an exploratory factor analysis and calculating Cronbach's alpha respectively.

\section{Empirical Results}

The main aim of this study was to determine if financial risks, such as oil prices, foreign exchange rates, interest rates, supply and demand, and liquidity and equity risks have a significant impact on the key performance variables, such as profitability, cash flow, the cost of doing business, project completion and workforce cutting in the Nigerian petroleum industry. The results of the survey are reported in Table 1 and the empirical results in Table 2 based on a Likert scale indication of 1 to 5 with five being the highest.

Table 1: Financial Risk Impact on Key Performance Variables

\begin{tabular}{|l|c|c|c|c|c|c|}
\hline Impact of Integrated risk factors & Low & Average & High & Mean & Rank & SD \\
\hline Profit reduction & 0 & 16 & 54 & 4.23 & 1 & 0.82 \\
\hline Cash flow reduction & 2 & 16 & 52 & 3.94 & 3 & 0.76 \\
\hline The increased cost of doing business & 5 & 11 & 54 & 4.04 & 2 & 0.89 \\
\hline Shelving of projects & 9 & 18 & 43 & 3.54 & 5 & 0.99 \\
\hline Workforce cutting & 12 & 18 & 40 & 3.60 & 4 & 1.12 \\
\hline Average & $\mathbf{5 . 6}$ & $\mathbf{1 5 . 8}$ & $\mathbf{4 8 . 6}$ & $\mathbf{3 . 8 7}$ & & $\mathbf{0 . 9 2}$ \\
\hline
\end{tabular}

As shown in Table 1, most of the respondents agreed that financial risk factors (low oil and gas prices, higher interest rates, low demand for commodity and exchange rate fluctuation) resulted in reduced profitability in the Nigerian petroleum industry with a mean score of 4.23 . This is followed by an increased cost of doing business with a mean score of 4.04 and then cash flow reduction with a mean score of 3.94. Next, is the widespread workforce cutting with a mean score of 3.60 and lastly, the shelving of projects has a mean score of 3.54. These results indicated that the combined financial risk factors had a negative influence on companies' ability to achieve their strategic objectives in the Nigerian petroleum industry. 
Table 2: The Influence of Financial Risks on Key Performance Variables - The Pearson Correlation Results

\begin{tabular}{|l|c|c|c|c|c|}
\hline $\begin{array}{l}\text { Key performance } \\
\text { variables }\end{array}$ & Forex & $\begin{array}{c}\text { Commodity } \\
\text { prices }\end{array}$ & $\begin{array}{c}\text { Interest } \\
\text { rates }\end{array}$ & $\begin{array}{c}\text { Supply and } \\
\text { demand }\end{array}$ & $\begin{array}{c}\text { Liquidity and } \\
\text { equity }\end{array}$ \\
\hline Profitability & $0.41^{*}$ & $0.38^{*}$ & 0.12 & $0.25^{*}$ & 0.15 \\
\hline Cash flow & $0.29^{*}$ & $0.29^{*}$ & $0.29^{*}$ & $0.29^{*}$ & $0.29^{*}$ \\
\hline Cost of doing business & $0.26^{*}$ & $0.26^{*}$ & $0.26^{*}$ & $0.26^{*}$ & $0.26^{*}$ \\
\hline Project completion & 0.11 & 0.11 & 0.11 & 0.11 & 0.11 \\
\hline Workforce & 0.11 & 0.11 & 0.11 & 0.11 & 0.11 \\
\hline
\end{tabular}

Note: * indicates significance at $\mathrm{p}<0.05$

The Pearson correlation results largely supported the respondents' views that the integrated financial risk factors was destabilising the finances of these Nigerian oil companies' ability to meet planned objectives. The results revealed that profitability, cash flow and the cost of doing business were significantly influenced by the negative effects of financial risks, except the impact of interest rate on profitability. The respondents were, therefore, correct in their assessment that the financial risks exerted an influence on key performance variables, such as profitability, cash flow and the cost of doing business in the Nigerian petroleum industry.

\section{Discussion}

\subsection{Impact of Financial Risks on Profitability}

The Pearson correlation coefficient revealed that profitability, which is key to the ability of companies to take up net present value investment, is significantly correlated to the foreign exchange variability of the Naira, oil and gas prices, and supply and demand pressure, as shown in Table 2. In the study, Mr A, who is from an upstream organisation, said, "It affects the profit margin of the organisation and it also affects the cash flow." Mr B commented, "It can impact the organisation in various ways, it can lead to a reduction in profit." Mr D, a financial risk manager whose organisation operates in both the downstream and upstream sectors of the Nigerian petroleum industry, remarked, "What we get from sales is always dictated by the exchange rate of the Naira." Interviewees reported that the negative impact of financial risks in the industry had reduced profitability as the margin was being squeezed to the point that no new projects were taking place in the industry. Companies were divesting themselves of projects instead.

This result is in sharp contrast to that of George et al. (2013) where financial risks have no significant correlation to the profitability of Kenyans' sugar industry. However, Rigzone (2014, p. 1) supports the argument that price fluctuation, as a result of oversupply and low world demand for oil and gas, was putting serious pressure on profitability. Therefore, the implication is that the sustainability of the petroleum industry can only be achieved through effective management of financial risks to avoid a distressing situation. The effect of financial risk movements on the profitability of the petroleum industry also has implications for decisions on oil production, sales, cost management and the financial leverage structure.

\subsection{Impact of Financial Risk on Cash Flow}

The result of the study showed that the integrated effect of foreign exchange, commodity prices, interest rates, supply and demand pressures, and liquidity and equity risks had impacted on the flow of funds significantly in the Nigerian petroleum industry. The interviewees supported the view that financial risks had a negative influence on the cash flow of their businesses. Mrs E remarked, "Right now, as I speak, there are some workers that are due for payment of housing scheme that has not been paid due to cash flow." This indicated that cash flow had taken a severe blow from the negative impact of financial risks to the point of leaving companies in the Nigerian oil and gas sectors with less cash to make payments as at when due. $\mathrm{Mr} \mathrm{C}$, who is the financial risk manager of a downstream organisation in the Nigerian petroleum industry, remarked, "Yes, it has impacted the cash flow. Right now, we utilise what we have within the reach of the organisation rather than longing for finances. So, because of that, it also reduces the rate of our activities in the business. As it stands now, it is very difficult to give facilities to the customers, because we are not getting facilities from the banks. In recent times, the Central Bank of Nigeria policies have made the impact to be on the higher side." The preceding comment indicated that the effect of financial risks had made it impossible to borrow money from banks and meant that customers in the industry were no longer given credit. Investment in new projects also suffered as a result of low cash flow in companies.

On one hand, this result contradicted the findings of Bartram et al. (2010) where financial and operational hedges reduced the impact of financial risks in companies' financial performance. The result did not also support the findings of Zhao (2010), Brooks \& Prokopezuk (2011), and Apergis \& Miller (2009). On the other hand, it was in congruence with the finding of Bartram (2007) that US companies' cash flows were exposed to at least one major currency exchange rate changeability. It was also in accordance with the finding of Krapl (2017) that financial risk factors and cash flow had a significant effect on equity exposure. Since financial stability is linked to every other business decision, the effect of financial risk exposure on cash flow may have implications on cost, investment and gearing. As this could lead to cost management that may even harm the business, postponement 
of already planned investments, and reliance on financiers for operations that would have otherwise been funded internally, it may put more pressure on interest expenses.

\subsection{Impact of Financial Risk on the Cost of Doing Business}

The results revealed that there was a significant correlation between the examined financial risks and the cost of doing business in the Nigerian petroleum industry, indicating that the prolonged low prices of petroleum products adversely impacted the financial well-being of companies in the industry. The depreciating Naira against major currencies adversely affected the cost of the importation of equipment and petroleum products, thereby reducing profitability and sustainability in the industry. The interviewees confirmed that the cost of doing business had increased as a result of the falling Naira against major trading partners' currencies. Mr B remarked, "The local cost has been well managed with the structure that we have. Where we have bigger issues are the ones related to foreign cost in terms of getting capital and equipment in and that is ... most of the costs are denominated in um ... foreign currencies, so any slight exchange rate fluctuation can affect us heavily." The preceding comments implied that the depreciating Naira had increased the cost of importing equipment for projects.

The result supports the finding of Kayalar et al. (2016) that currency risk significantly affects most oil exporter countries' share prices, but not on importers' economy. The results were in congruence with the results of the study, which investigated oil volatility spill-over on Nigeria sovereign bond (Tule et al., 2017). The low demand and oversupply of petroleum products seriously reduced the ability of companies to meet profit targets, cash flow requirements for the development of new oil wells and the retention of their skilled workforce.

The Pearson correlation coefficient results, however, showed that the financial risks were not significantly related to project completion or workforce cutting as key performance variables. On one hand, it indicated a possible dissonance between respondents' qualitative assessments of the effect of these risks on these key performance variables and the other hand, how they quantified these effects. This could also present an interesting area for future research. The question that needs to be answered was whether a proper quantification of the effect of financial risks on project completions (versus shelving) and workforce reductions, was taking place.

\section{Conclusion}

This study examined the impact of financial risk factors - foreign exchange, commodity prices, interest rates, supply and demand pressures, and liquidity and equity risks on key operational variables - profitability, cash flow, cost of doing business, workforce cutting and shelving of projects of the Nigerian petroleum industry. This study employed primary data to evaluate the impact of financial risks on financial performance, which set this study apart from the numerous kinds of literature on the impact of financial risks on equity. The study also differentiates itself further by dealing with an integrated effect of various financial risks instead of reviewing each risk factor in isolation. It focused on the Nigerian petroleum industry where no other study of this nature has been conducted to the best knowledge of the authors.

The findings showed that financial risks factors had a significant negative effect on profitability which impacts the sustainability of the businesses. It also revealed that their cash flow was adversely affected through reduced inflows associated with these risks' factors. Another key finding was an increase in the cost of doing business arising from higher input costs. It, however, showed that financial risk factors had less impact on workforce cutting/retrenchment and project shelving. The result of this research has implications for various stakeholders in the Nigerian Petroleum industry such as the management of petroleum companies; managers of financial risks in the industry; regulators of the industry; the Nigerian government and investors in the industry. These results are important to the financial risk managers and management of the industry as it will help them understand how to manage their exposure for sustainability. It will guide the government and the regulatory bodies in policy formulation to encourage effective risk management. Investors will also find this article useful by understanding the financial risks involved in investing in the petroleum industry.

These papers make the following recommendations that managers can implement to improve financial risks management in the oil industry:

- Managers must pay serious attention to the managing of the financial risks identified in this study, especially oil and gas price, exchange rate, and demand and supply risks.

- Educate employees of the implication of their actions and inactions on the key operational variables.

- Management support is essential in availing employees of a warning system that would show the extent of these impacts will be very helpful

- Leveraging the intellectual property of the organisation to mentor more employees on risk management processes as the present level of knowledgeable skilled-risk-experts is very low.

Like any other scholarly work, this article is not without limitations. Even though a total of one hundred questionnaires were administered, only 70 managers responded due to refusal to participate in the survey. A larger sample size which could include more expert financial risk managers may enhance future research. 


\section{References}

Ahmed, H. J. A., Bashar, O. H. M. N., \& Wadud, I. K. M. M. (2012). "The transitory and permanent volatility of oil prices: what implications are there for the US industrial production?” Appl. Energy 92, 447-455.

Algieri, B. \& Leccadito, A. (2017). "Assessing contagion risk from energy and non-energy commodity markets." Energy Economics, 62, 312-322.

Al-Shboul, M., \& Alison, S. (2009). "The effect of the use of corporate derivatives on the foreign exchange rate exposure" Journal of Accounting-Business and Management, 16(1), 72-92.

Andriospoulos, K. \& Nomikos, N. (2012). "Risk management in the energy market and value at risk modelling: a hybrid approach." The European Journal of Finance, 21:7, 548-574, DOI: 10.1080/1351847X.2013.862173.

Apergis, N. \& Miller, S. M. (2009). "Do structural oil-market shocks affect stock prices?". Energy Economics, 31(4), 569-575.

Arong, F. E., \& Ikechuku, E. M. (2013). "The Perception of Nigerians on the Deregulation and Privatization Moves of the Government in the Oil and Gas Industry in Nigeria", International Journal of Public Administration and Management Research (IJPAMR), 2(1), 119-129. October 2013. Retrieved from: http://www.rcmss.com ISSN 2350-2231.

Arouri, M. E. H., Rault, C., \& Nguyen, D. K. (2012). "Oil prices and stock markets in GCC countries: empirical evidence from panel analysis". Economic Modelling 28 (2011) 1815-1825.

Askari, H. \& Krichene, N. (2008). "Oil price dynamics (2002-2006)." Energy Economics 30, 2134-2153.

Bagehot, M. \& Atima, T. O. (2015). "The impact of petroleum on economic growth in Nigeria." Global Business and Economics Research Journal, 2, 102-115.

Bartov, E., \& Bodnar, G. M. (1994). "Firm valuation, earnings expectations, and the exchange rate exposure effect." Journal of Finance, 49, 1755-1785.

Bartram, S. M. Brown, G. \& W. Minton, B. A. (2010). "Resolving the exposure puzzle: The many facets of exchange rate exposure." Journal of Financial Economics, 95, 148-173.

Bartram, S. M. (2007). "Corporate cash flow and stock price exposures to foreign exchange rate risk," Journal of Corporate Finance, 13, 981-994 DOI: 10.1016/j.jcorpfin.2007.05.002.

Basher, S. A., Haug, A. A. \& Sadorsky, P. (2012). "Oil prices, exchange rates, and emerging stock markets," Energy Economics, 34, 227-240.

Brooks, C. \& Prokopezuk, M. (2011). "The Dynamics of Commodity Prices. Reading," ICMA Centre Discussion Papers in Finance, DP2011-09.1-44.

Buckley, A. (2004). "Multinational Finance," (5th edition) Pearson Education Limited Prentice Hall Edinburgh Gate

Chaudary, S., Nisar, S., Talat, A. \& Salvador-Adebayo, D. (2014). "Stock Market a Proxy for Oil Prices - A Focus on the Nigerian Economy." Pakistan Journal of Commerce and Social Sciences, 8 (3), 780-797.

Chow, E. D., Lee, W. Y. \& Solt, M. E. (1997). "The Exchange-Rate Risk Exposure of Asset Returns." Journal of Business, 70, 105-123.

Damodaran, A. (2008). "Strategic Risk Taking: A framework for Risk Management." Pearson Education, Inc. New Jersey

Dhanani, A., Fifield, S., Helliar, C and Lorna Stevenson, L. (2008)." The management of interest rate risk: evidence from UK companies." Journal of Applied Accounting Research 9 (1), 52-70 DOI $10.1108 / 09675420810886123$

Dhaoui, A. \& Khraief, N. (2014). "The empirical linkage between oil price and stock market returns and volatility: evidence from international developed markets." Economics Discussion Papers, No: 2014-12. Kiel Institute for the World Economy (http://www.economicsejournal. org/economics/discussion papers/2014-12).

Ehikioya, B. I. (2019). "The impact of exchange rate volatility on the Nigerian economic growth: An empirical investigation." Journal of Economics \& Management, 37(3), 45-68. https:// doi.org/10.22367/jem.2019.37.03

EIA, " (2013). "Oil and Natural Gas in Sub-Saharan Africa." (https://www.eia.gov/pressroom/presentations/howard_08012013.pdf)

Elyasiani, E., Mansur I, \& Odusami B. (2011). "Oil price shocks and industry stock returns." Energy Economics, .33, 966-974.

Eni. (2013). "Annual Report / Risk Management 2013; Annual report." 1-272 Retrieved from https://www.eni.com/docs/en.../enicom/.../reports/reports-2013/Annual-Report-2013

Ewing, B. T., \& Malik, F. T. (2015). "Volatility Pullovers between Oil Prices and the Stock Market Under Structural Breaks." Global Finance Journal, 29, 12-23.

Gao, T. (2000). "Exchange rate movements and the profitability of US multinationals." Journal of International Money and Finance, 19, 117-134.

George, G. E., Ouma, B. O. \& Were, J. N. (2013). "Effect of financial risk on the profitability of sugar firms in Kenya." European Journal of Business and Management, 5, 2222-2839.

Hekman, C. R. (1989). "Measuring the impact of exposure." Management of Currency Risk, Boris Antl, 49-52. 
Hong, G. \& Sarkar, S. (2008). "Commodity betas with mean-reverting output prices." Journal of Banking and Finance, 37, 1286-1296.

Horcher, K. A. (2005). “Essential of financial risk management.” John Wiley \& sons, Inc New Jersey

Huanga, P., Kabir, M. H, \& Zhang, Y. (2016). "Does Corporate Derivative Use Reduce Stock Price Exposure? Evidence from UK Firms." The Quarterly Review of Economics and Finance $\mathrm{xxx}$ (2017) xxx-xxx article in press1-9.

Hutson, E. \& Laing, E. (2014). "Foreign exchange exposure and multinational." Journal of Banking \& Finance, 43, 97-113.

Jongen, R., Muller, A., \& Verschoor, W. F. C. (2012). "Using survey data to resolve the exchange risk exposure puzzle: Evidence from U.S. multinational firms." Journal of International Money and Finance. 31, $148-169$.

Jorion, P. (2009). "Risk management lessons from the credit crisis." European Financial Management, 2009, 120. Retrieved 23 April 2012, from http://merage.uci.edu/ jorion/papers\%5CRiskMgtCreditCrisis.pdf.

Kamau, P., Inanga, E. L. \& Rwegasira, K., (2015). "Currency risk impact on the financial performance of multinational banks." Journal of Financial Reporting and Accounting, 13, 91-118.

Kayalar, D. E., Küçüközmen, C. C. \& Selcuk-Kestel, A. S. (2017). "The impact of crude oil prices on financial market indicators: copula approach." Energy Economics, 61, 162-173.

Kolodziej, M., Kaufmanna, R. K., Kulatilaka, N., Bicchetti, D. \& Maystre, N. (2014). "Crude oil: Commodity or financial asset?" Energy Economics, 46, 216-233.

Krapl, A. A. (2017). "Asymmetric foreign exchange cash flow exposure: A firm-level analysis." Journal of Corporate Finance, 44, 48-72.

Lin, C. (2012). "The co-movement between exchange rates and stock prices in the Asian emerging markets." International Review of Economics and Finance, 22, 161-172.

Moore, T., \& Wang, P. (2014). "The dynamic linkage between real exchange rates and stock prices: evidence from developed and emerging Asian markets." International Review of Economics \& Finance, 29, 1-11.

Nkalu, N. C., Urama, N. E. \& Asogwa, F. O. (2016). "Trade Openness and Exchange Rate Fluctuations Nexus in Nigeria." European Journal of Scientific Research ISSN 1450-216X/1450-202X Vol. 138 No 3 March 2016, pp.139-144 http://www.europeanjournalofscientificresearch.com

Nikbakht, L. (2010). “Oil Prices and Exchange Rates: The Case Of OPEC.” Business Intelligent Journal 3(1) 83 92

Noor, J. A. M., \& Abdalla, A. I. (2014). "The Impact of Financial Risks on the Firms.” Performance. European Journal of Business and Management.6, .5, 2014 retrieved from https://www.iiste.org/Journals/index.php/EJBM/article/view/10917.

Odularu, G. O. (2007). "Crude Oil and the Nigerian Economic Performance," Oil and Gas Business, 1-29. Retrieved from http://www.ogbus.ru/eng/authors/odularo/ odularo_1.pdf.

Ojongbo, O. C., (2014). The Impact of Real Exchange Rate Fluctuation on Industrial Output in Nigeria. Journal of Policy and Development Studies, 9(1), 269-278.

Oladepo, O. I. (2014). "Evaluation of Petroleum products marketing in a globalising economy: A conceptual evidence from Nigeria," Journal of Marketing Studies, 2(2), 71-81. Retrieved from http://www.eajournals.org.

Prasad, K. S., \& Suprabha. (2015). "Measurement of exchange rate exposures: Capital market approach versus cash flow approach." Procedia Economics and Finance, 25, 394-399.

Rigzone. (2014). "Will the Saudis drive US shale out of Business?" Retrieved from https://es.scribd.com/.../RIGZONE-Kemp-Will-the-Saudis-Drive-US-Shale-Out-of-Bus

Sadorsky, P. (2012). "Correlations and Volatility spill overs between oil prices and the stock prices of clean energy and technology companies" Energy Economics, 34, 248-255.

Shaeri, K. Adaoglu, C., \& Katircioglu, S. T. (2016). "Oil price risk exposure: A comparison of financial and nonfinancial." Energy, Volume 109, 712-723.

Stober, E. O. (2016). "Crude Oil Price Shocks and Macroeconomic Behaviours in Nigeria." Journal of Social and Economic Statistics, 5, No. 1, 56-67.

Stulz, R. M. (2008). "Risk Management Failures: What Are They and When Do They Happen?" Journal of Applied Corporate Finance, 20(4), 39-48. doi/10.1111/j.1745-6622.2008.00202.

Talbot, E. Artiach, T., \& Faff, R. (2013). "What drives the commodity price beta of oil industry stocks?" Energy Economics, .37, 1-15.

Tomlin, B, (2014). "Managing supply-demand risk in global production: Creating cost-effective flexible networks". Business Horizons, 57, 509-519

Tsai, I. (2012). "The relationship between stock prices and exchange rates in Asian markets: A quantile regression approach." 22, 609-621.

Tule, M. K., Ndakob, U. B. \& Onipede, F. B. (2017). "Oil price shocks and volatility spill overs in the Nigerian sovereign bond market." Article in press. Review of Financial Economics, $\mathrm{xxx}$ (2017) $\mathrm{xxx}-\mathrm{xxx}$ 
http://doi.org/10.1016/j.rfe.2017.03.003.

Umaru, H., Aguda, N.A., \& Davies, N.O. (2018). "The Effects of Exchange Rate Volatility on Economic Growth of West African English-Speaking Countries," International Journal of Academic Research in Accounting, Finance and Management Sciences 8 (4): 131-143

Wiener, M. \& Brunner-Kirchmair, T. M. (2019). "Knowledge is power-conceptualizing collaborative financial risk assessment.” The Journal of Risk Finance, 20 (3): 226-248 DOI 10.1108/JRF-05-2018-0083

Woods, M. \& Dowd, K. (2008). "Financial Risk Management for Management Accountants." Charted Institute of Management Accountant, pp. 1-27.

Ye, M., Hutson E. \& Muckley, C. (2014). "Exchange rate regimes and foreign exchange exposure: The case of emerging market firms." Emerging Markets Review. 21, 156-182.

Zahariev, A. \& Kostov, D. (2016). "The Price of Crude Oil as a Factor for USD Volatility". Economics and management organization.21. 15-23. 10.2139/ssrn.2915435.

Zhao, H. (2010). "The dynamic relationship between exchange rate and stock price: evidence from China." Research in International Business and Finance, 24 (2), 103-112. https://doi.org/10.1016/j.ribaf.2009.09.001 